\title{
MANAGING HUMAN RESOURCE THROUGH GREEN POLICY: WAYS OUT AND ITS IMPLICATION
}

\author{
Md. Miraj Hossen \\ miraj.hossen@yahoo.com \\ Mareum Begum \\ Huazhong University of Science and Technology (HUST) \\ 1037 Luoyu Road, Wuhan 430074, Hubei, P. R. China. \\ Fatema Sultana \\ Department of Management, Jashore University of Science and Technology (JUST) \\ Jashore, Bangladesh
}

received: 23/8/18; revised: 17/12/18; published: 31/12/18

\begin{abstract}
This paper attempts to highlight the green policy and its practices for managing the human resource in the organizations and also seeks to ways out some techniques to make green HR policy useful for the organizational practices. In this study, the authors used secondary data through an extensive literature survey form different sources. The significant findings are that all over the world, organizations are trying to practice green management or implementation of green policy for their daily activities as well as to ensure the health and well-being of their human resources. Though the green system is beneficial for both the organizations as well as employees but it costs a lot in the initial stage to meet up the preliminary fixed costs, train the people and to make people ready to work as per green policies. Gathering experiences from different research in advanced countries the authors try to conclude the study by mentioning some ways- how to manage HR through green policy or green human resource management (HRM) techniques.
\end{abstract}

Keywords: environment management; green management \& policy; green initiatives; HRM

\section{INTRODUCTION}

Human resources are the most prominent assets and also considered as the driving force of any organization whether it is service or manufacturing business. To keep them happy and safe with good health; green issues come to the organizational policy and practice. In the current business practices, all organizations have been showing the greatest interest in making the corporations greener. Nowadays the terms green policy, green management, green HRM, green banking, etc. are most pronounced to make the business organizations livable for their stakeholders. Considering the importance of green policy and environmental issue in the professional domain many ecologists around the world, try to create the mass awareness about the impacts of global warming and find out the possible solution to make the world livable (IDRBT, 2013). Building upon this green concept numerous literatures on Green marketing (Phillips, 2007), Green HRM (Wehrmeyer, 2017), Green management in general (McDonagh \& Prothero, 1997), Green accounting (Bebbington, 2000), proactive environmental management (González-Benito
\& González-Benito, 2006), and Green retailing (Lai, Cheng, \& Tang, 2010) have emerged the field of management. The contemporary attention in green policies globally has risen after specific agreements to fighting against climate change, e.g.; Kyoto 1997, Bali 2007 and Copenhagen 2009 (Victor, 2011). The effective environmental management and firm's environmental performance is an emerging agenda to global business leaders, (Berns et al., 2009; Longoni \& Cagliano, 2015).

Green policy can ensure the environmental sustainability through human resource by following the 3D approach-De-materialization, De-carbonization, and De-mobilization in the daily activities of the domains (Z. Chen, Hossen, Muzafary, \& Begum, 2018; Hossen, Uddin, \& Hossain, 2014). Though it was assumed previously that integrating 'green' into their business strategy would cost money, but they now realize that ignoring negative impacts on the environment will be costly in the future by performing green management, the businesses may earn the better profit than before (Murari \& Bhandari, 2011). If the organizations can perform better in their environmental learning and developing employees' environmental competencies, 
they will be capable of getting the opportunities of the green market in the shorter period (Svensson et al., 2016). Flammer (2013) have found that several positive outcomes, such as higher profitability, better financial performance, and higher stock prices come due to good environmental performance. Chadwick (2010) argued that HR practices affect organizational performance in three ways: additive effects (when they do not interact represented by the formula: $2+2=4$ ); substitution effects (when they present equifinality, i.e., $2+2=3$ ); and synergetic effects (when they reinforce each other, i.e., $2+2=5$ ). This type of relationship between environmental performance and organizational outcomes has been mediated by intangible resources, such as human capital and culture (Surroca, Tribó, \& Waddock, 2010), human resource management research (Bauer, Erdogan, \& Taylor, 2012; Jones \& Willness, 2013) and practice (DuBois \& Dubois, 2012) have given emphasized the relation between HRM practices and environmental management. (Zamil \& Hossen, 2012) argued that proper ICT with the green policy of any country plays an enormous role in case of business, commerce, and environmental sustainability.

To implement these green strategies, the business organizations need the active and dynamic leadership and concrete policies is first required (Glavas, Senge, \& Cooperrider, 2010). In organization, green teams help to generate the idea, motivate organization learning, identify and resolve conflicts by green policies and practices (Beard \& Rees, 2000). According to Mandip (2012), Green HR policy mainly consists of two primary elements namely environment-friendly HR practices and the preservation of knowledge capital. Nowadays, managing HR through green system is considered as one of the key business strategies for the corporations where Human Resource Departments can play an important role 'in the formation of their company's sustainability culture' (Harmon, Fairfield, \& Wirtenberg, 2010) as they are dealing with the driving force (HR) of the organization. Jackson, Renwick, Jabbour, and Muller-Camen (2011) argued that the success of Green HRM mostly depends on the HR manager's unique and identifiable patterns of green decisions and behaviors. In the concept of managing people through green policy, the entire functions of HRM is considered in the light of all over. In an organization, green management policies and strategies are the foundation of sustainable business as they are responsible for planning and executing the eco-friendly procedure to create a green atmosphere.

Though there is a numerous research regarding green issues in developed or even developing countries but there are still have a long way to go to ensure the utmost success all over the world. The most mentionable achievements can be found in the western countries and some other developed countries, but developing countries still lag behind. The concept of GHRM is popularly used and practiced in western countries, and it is an important issue to study for the Asian countries for their environmental management and economic development (D. W. Renwick, T. Redman, \& S. Maguire, 2013). Even though there are some developments in the concept but the volume of research focusing on Green policy for HRM remains insignificant and in the primitive stage and there are many gaps to be filled theoretically and empirically as well (Z. Chen et al., 2018; Jackson et al., 2011). So, the researchers think to work on this topic will be a great initiative and the parties related to the issue will be the optimum beneficiary along with the greater society.

The main purpose of this study is to know about the concept of green management and policy for managing HR within the organizations along with the following specific objectives: (1) Provide the basic concepts and highlight the significance of Green policy for HRM; (2) Have an idea about the green policies and practices in managing HR in organizations; (3) Attempt to ways out- how the organization can make effective green strategy for HRM.

Managing people through green policy is popularly known as green human resource management (GHRM). The term Green policy for HRM has become one of the most prominent topics in recent business research all-round the globe. Green HRM is the 'integration of corporate environmental management into human resource management' (Renwick, Redman, \& Maguire, 2008), 'the level of greening the functional dimensions of human resource management' (Jose Chiappetta Jabbour, 2011), 'the use of HRM policies to stimulate the sustainable use of resources within organizations' (Marhatta \& Adhikari, 2013), 'the use of HRM policies to inspire the sustainable use of resources within corporations and further boosts up employee morale and satisfaction (Mampra, 2013), 'the use of HRM policies, philosophies, and practices to ensure sustainable use of business resources and thwart any untoward harm arising from environmental concerns in organizations' (Zoogah, 2011). The purpose of Green policy for HRM is to create the positive atmosphere within the organizations so that an employee can give a maximum individual contribution on each of the four roles, i.e., preservationist, conservationist, non-polluter, and maker (Opatha \& Arulrajah, 2014).

Green HRM is the process of recruiting, hiring, training, compensating, developing, and advancing the firms human capital intending to creating the green workforce that understands, appreciates, and practices green initiative and maintains its green objectives all throughout their activities (Mathapati, 2013). The green HR policy considers every employee to stimulate sustainable environmental practices and upsurge employee consciousness and promises on the issues (Mandip, 2012). It also emphases on employee's ecological performance within the organization as well as in their private life (Muster \& Schrader, 2011). In 
the sense of Opatha and Arulrajah (2014), Green HRM is the way of changing current workforces into green workforces to achieve organizational environmental goals and to make a noteworthy contribution to environmental sustainability. According to Malu, Agrawal, and Jajoo (2014), by introducing sustainable policy, the business organization can play a significant role to preserve the environmental sustainability with the conscious human resources.

Human Resource Management (HRM) is the combination of several functions related to acquisition, development, motivation, and retentions of HR within the organizations. Renwick et al. (2008), argued that reliable and effective policies in the field of HRM systems act as the principal tools for engaging employees with environmental performance of a company. To achieve the environmental sustainability the organization must have an effective HRM practices including strict recruitment strategies (Grolleau, Mzoughi, \& Pekovic, 2012; Hossen et al., 2014), appraisal, and reward systems which embrace environmental consciousness and execution it in their performance assessment process (Jabbour, de Sousa Jabbour, Govindan, Teixeira, \& de Souza Freitas, 2013) and employee training, development and empowerment programs (Unnikrishnan \& Hegde, 2007) which will help to develop a new set of skills, abilities, knowledge and attitudes among the employees of 'progreen' organizations. Cherian and Jacob (2012) in their research acknowledged that recruitment, selection, training \& development, employee motivation, rewards $\&$ benefits are essential human magnitudes which subsidize to the enhancement in employee's drives to green management principles. After reviewing different kinds of literatures, the major finding related to the importance of making specific functions green can be listed below:

Acquiring qualified and environment conscious employee is one of the preconditions of effective use of GHRM in the organization but attracting highlyskilled staffs is one of the HR challenges in the 'war for talent' (D. W. Renwick et al., 2013). Nowadays, firms are trying to gain the reputation as a green employer by practicing GHRM in a way to appeal new talents (Stringer, 2010). In the competitive market, job hunters prefer 'Green Organizations' as their working destinations whereas employers are looking for 'Green job candidates' all through their recruitment processes (Hossen, Begum, \& Zhixia, 2018; D. W. Renwick et al., 2013), recruiting those candidates who can able their green values within the organizational activities to ensure corporate sustainability (Phillips, 2007; Stringer, 2010). Moreover, several empirical research suggested that green-related information in their company websites and job advertisements attracts the attention of the and improves the probabilities of appealing and employing competent candidates (Bansal \& Roth, 2000; Gully, Phillips, Castellano, Han, \& Kim, 2013; Jabbour, Santos,
\& Nagano, 2010). For these cases, companies should consider the practices GHRM and provide sufficient information on their websites to attract qualified potential employees (C.-C. Chen, Lin, \& Chen, 2012; Gregory, Meade, \& Thompson, 2013). Grolleau et al. (2012) in their study, found that professionals are more conscious about the sustainable environmental policies and practices of a company. CIPD/KPMG has surveyed on $1000 \mathrm{HR}$ specialists and found $47 \%$ professionals stated that they prefer working for those firms that have a robust Green approach, and this would appeal prospective high-skilled workforces(Phillips, 2007).

Green training focuses on the development of employees' such types of abilities and to prevent deterioration of environment management (EM)-related knowledge, skills, and attitudes (Zoogah, 2011). All the employees of an organization should be acquainted with environmental management training as a means of the major success factors of the organizational sustainable environment (Unnikrishnan \& Hegde, 2007). Green training and development informed employees to work with the methods that save energy, condense waste, diffuse ecological mindfulness within the organization, and provide the chance to involve employees in environmental decision making and problem-solving (Zoogah, 2011). Green training issues is given prioritized in some developed or even developing countries. In the UK, a CIPD/KPMG study stated $42 \%$ of UK organizations providing green training to their employees to make the business activities environment-friendly (Phillips, 2007) and make them capable to works against the threats of climate change and its impacts on firms (do Rosário Cabrita, CruzMachado, Matos, \& Safari, 2016). In the regime of the Obama administration, the US has been invested $£ 300 \mathrm{~m}$ in training for Green jobs (Barton, 2009).

Green performance appraisal (PA) consider the issues such as environmental incidents, environmental knowledge, use of environmental responsibilities and the communication of environmental concerns and policy within the employees and organizations (Clair \& Milliman, 2017). When HR managers incorporate environmental performance into PM systems they mainly introduce the protection against any damage in the firm's environment management systems (Epstein \& Roy, 1997), by introducing organization-wide environmental performance standards, and Green information systems, audit to gain on ecological performance firms try to deal with the issue of PM (Alfred \& Adam, 2009; Marcus et al., 2007). A capable performance management system can offer worthwhile feedback to performers and constantly help to the developments in the firm's environmental outcomes (Jackson et al., 2011). Issues related to the environmental PA concern the need for managers to be held accountable for EM performance in addition to broader performance objectives (D. W. Renwick et al., 2013). 
In the modern organizations, compensation and benefits are considered as one of the most influential means to links an individual's interest to that of the organization's together for supporting environmental activities. According to Liebowitz (2010), employee compensation programs can be modified to give bonuses and awards based on their excellent performance in special projects and green management. Green rewards can embrace the use of workplace and lifestyle benefits, alternating from carbon credit offsets to free bicycles, to involve employees in the green management while enduring to acknowledge their contribution (Pillai \& Sivathanu, 2014). In the UK, some company practice the use of a 'carbon credit card' and cash incentives for staff to purchase hybrid cars (Davies \& Smith, 2007), arrange annual honor dinners to acknowledge exemplary performance in environmental management (Simms, 2007), and financial incentives also paid as reward (such as tax incentives and exemptions to promote loaning bicycles to employees, and the use of a less polluting car fleet) for their environmental performance (Davies \& Smith, 2007). A study conducted in the UK by CIPD/KPMG and found that $8 \%$ of UK firms were rewarding green behaviors with financial and/ or non-financial incentives (Phillips, 2007); and these practices acts as an effective tool to motivate employees toward eco-initiatives within the organizations (Ramus, 2002). The best practices of green compensation can be observed in US firms- they paid more their CEO's of eco-friendly firms than non- eco-friendly firms which exhibit the strong relationships between environmental performance and CEO's total pay (Berrone \& GomezMejia, 2009).

A good employee relation is an intangible and long-term asset for any organization which can help to achieve a competitive advantage. Employee involvement in Green decision-making process increases the chances of better green management practices and systems. The accomplishment of green results generally depends on employees' eagerness to cooperate (Collier \& Esteban, 2007), as often, the best ideas come from the employees who work in that particular area (Casler, Gundlach, Persons, \& Zivnuska, 2010). Wider employee participation in EM considered as the important factors to get successful outcomes rather than limiting participation to managers and specialists (Hanna, Rocky Newman, \& Johnson, 2000; Remmen \& Lorentzen, 2000). Including staffs in environment management (EM) decision-making process has been considered as improving the key outcomes of EM systems, including efficient usage of resources (Z. Chen et al., 2018; Florida \& Davison, 2001); decreasing waste and workplaces pollution (Kitazawa \& Sarkis, 2000). Different employee involvement programs can be used in EM systems such as newsletters, suggestion schemes and problem-solving groups (D. W. Renwick et al., 2013), work-based recycling schemes (D. Renwick, T.
Redman, \& S. Maguire, 2013); forming Green teams to make firms environment friendly (MOHD-YUSOFF \& MOHD-YUSOFF, 2015); and inspiring employees to use telecommuting, video conferencing, car-sharing, and home-working (Philpott \& Davies, 2007). Employee involvement in green and environment management is also helpful to upsurge the employee's health and safety, as well as the development of eco-friendly staff.

Supportive organizational culture can inspire staffs to make propositions for and the autonomy to participate in the activities that develop the environment of the workplace (Madsen \& Ulhøi, 2001). It will not work and give the optimum outcomes in long-term environmental sustainability until changing the corporate culture along with the changes in man, machine, material and other things(Kitazawa \& Sarkis, 2000; Stone, 2000). Management should empower employee in the EM systems decision-making process, try to win their 'hearts and minds' to the environmental cause, motivate them to 'buy-in' to taking ownership of energy management use (Trust, 2006). Employee personal values, such as openness to change, are positively correlated with positive attitudes towards the environment (Chun, 2009). However, the long-term problems of supporting pro-environmental cultures, with managerial and supervisory changes damaging employee commitment to environmental management initiatives(Forman \& Jorgensen, 2001). Different studies in UK and US companies suggest that employee empowerment acts as the feelings of psychological empowerment which also upsurge their willingness to work proactively for environmental improvements (Kitazawa \& Sarkis, 2000). A survey on 232 Australian manufacturing firms reports that there is a positive relationship between the employee's environmental performance and the level of employee empowerment (Simpson \& Samson, 2010).

\section{METHOD}

The study is mainly descriptive in nature based on an extensive literature survey of secondary data. According to Mugenda (2003), a descriptive survey design helps a researcher to gather, summarize, present and interpret information for clarification. The study has been designed intending to investigate and determine the significance of practices green policy for managing HR within the organization. For secondary data, the researchers have reviewed many articles cited in the databases Sage, Taylor and Francis Online, Elsevier, Springerlink, ScienceDirect, JSTOR, Wiley Online Library, and Emerald related to green management, green HRM or environmental HRM.

\section{RESULTS AND DISCUSSIONS}

Green organizational practice is mostly needed in the modern business area as the world climate is changing 
and becoming unhealthy for the survival of human being. Every year we face different types of natural disasters such as storms, floods, droughts, earthquake, excessive heat and melting ice, acid rains, red rains, Tsunamis, etc. Ecologists in the world suggested making a natural balance from every corner of the world for the survival of the planet. Green HRM helps to create three pillars like- environmental sustainability, social sustainability, and economic sustainability (Yusoff, Ramayah, \& Othman, 2015). Fortunately, some governments, organizations, and individuals including environmentalists and nature lovers come forward and pay serious attention to preserve and conserve the environment. Green HRM is one of the parts of making organization green to make sure the environmental sustainability. Practicing green HRM is helpful for the organization as well as the society in the following ways: (1) Minimizes natural disasters, health diseases, global warming due to pollution; (2) Ensures the survival of humans and business organizations and ecological balance; (3) Increases employee productivity through satisfaction and better efficiency; (4) Lesser consumption of power-energy, water, and raw materials; (5) Attracts best talented HR and ensure to retain them for the longer period; (6) Increase organizational scale sales and areas services; (7) Creating the brand image for the organization that becomes a competitive edge as well; (8) Dropping costs due to electronic documentation, teleworking, video conferencing, recycling of different usable products within the organizations.

These benefits are considered from both economic and environmental perspectives of the organization, and finally it helps to gain the organizational competitive advantage as well as a strategic advantage. The HR Managers of modern organizations are much more conscious about creating the awareness among the young employees of the organizations of Green HRM.

Implementing green policies for human resource need to meet up some requirements otherwise the organizational green target or environmental goals will fail. Green HRM policies mainly require the following things, Figure 1.

Green competencies are essential to the effective implementation of green HR policy for managing the human resource. Without a sufficient amount of knowledge and skills, it is not possible for the employee to become a Green employee. Beside these, the employee needs to have a right attitude of Greening. Right attitude means appropriate beliefs (cognitive), feelings (affective) and intention to behave (behavioral) concerning greening. Finally, green policy implementation required green behavior or positive actions of employees towards achieving organizational green targets. The outcome of green HR policy of an organization leads to better environmental management as well as better employee and customer's satisfaction.

To ensure the optimum outcomes regarding green issues, every organization needs to adopt some policies to make employees green and achieve green benefits. To ensure optimum productivity through HR, the organizations need to make sure the formulation and proper practices of green policies for each function of HRM. Moreover, Table 1 may help the organization to formulate and practices green policy for the better of the organization as well as their employees' well-being.

Individual as an employee of any organization can play four roles (preservationist, conservationist, non-polluter, and maker) to become a green employee or implementing green policies in the organizations. Preservationist(s) are aware of protecting the environment from harm, loss, or adverse change. Conservationist(s) are very careful of using the environment so that future generations will be able to utilize it. Non-polluter(s) are always trying to prevent air, water, atmosphere, etc. from contamination. Maker(s) are willingly built parks and places which have plants, trees, and grass like a garden. Moreover, an individual can play roles in different ways to make sure the proper implementation of green policy by practicing the following activities: (1) To reduce electricity consumption- an individual employee can drink natural water rather than refrigerated water, keep the computer off when not working, use daylight and/or work with the minimum number of bulbs as much as possible; (2) To save environment and trees- use the electrical filing system rather than printed documents but if needed use both sides of the paper when writing or printing or photocopying; (3) To reduce air pollution- come to work by using public transport or official transport whenever possible, stop throwing wastages outside or anywhere, recycle or re-use some office stationaries items; (4) To keep them safe and healthier- employees can put plants in their workspaces, bring his or her mugs/glass, plates, foods, and also order organic foods for parties; (5) To be the part of the green achievements- every employee should obey the organizational green policy and code of conduct.

In today's organizations, green initiatives for managing HR is considered as a part of the corporate social responsibility and always monitoring the green practices and its achievements. Many organizations all over the world are integrating and working toward executing green policies and practices to achieve competitive benefits in the business domain. There are many issues related to green policy for HR that is to be considered by an organization's HR department before executing green initiatives which are not a task for a single day somewhat continuous process. Considering these things, organizations can take or some organizations have taken different actions as part of their green policy which can be listed below: (1) Adoption of green buildings by organizations while dealing with environmental issues. This building can ensure the uses of sunlight to reduce the electricity consumption; (2) 
Mission to make paperless office which encourages digital filing systems and database management and also help to conserve trees, prevent pollution, and reduce wastage; (3) Encourages employees to use public transport or official vehicles for their daily commute to the workplace to save fuel and the environment also; (4) Save the environment by using 3R methods- reduce, reuse, and recycle of wastages and to do it supply recycled trash bins, recycled use of water for gardens and plants; (5) Use energy efficient air conditioners, bulbs and heaters to conserve the power uses; (6) Introduce video conferencing, teleconferencing, teleworking, telecommuting and other internet applications used for meetings thereby bringing down business travel and work from out of office; (7) Arrange a smoking zone and make sure the office is smoke-free for all stakeholders; (8) Train the employees to create green awareness and implement the green policies and also rewards those who are coming up with sustainable green ideas and strategies; (9) Encourage employees to keep some plants in their workspace and centrally follow tree plantation in the compound of the workplace.

\section{CONCLUSION}

As we are born and brought up by nature and always getting care by nature, it's our responsibility to preserve the balance of life through ensuring environmental sustainability. Managing people through green policy is one of the extended techniques to provide ecological balance. Though it's the responsibility of HR managers to create awareness to youngsters and other working people about green movement, preserving natural resources and preserving environmental sustainability (Hossen et al., 2014; Mathapati, 2013); but the organization's culture and employee's mindsets are essential to ensure green management within the organization - this is the point why we need green policy. If we can ensure green policy for human resources; of course the working people will bring the most desired result for the environmental achievement in the organizations. If the organization can make sure the successful implementation of green policy for HRM, it can ensure three types of sustainability (environment, social, and economic) for the organizations (Z. Chen et al., 2018; Yusoff et al., 2015). Though many organizations and employees are well-informed regarding green HRM issues but the success is not still remarkable due to lack of investment, inadequate IT supports, proper policy, community, and governmental supports. After finishing the paper, the authors are the optimist about the near future that the day is not so far when all the organization will have a formal green policy for managing their human resources and which will also help the organizations to ensure the environmental sustainability and present a good working environment for their employees.
To make sure of proper implementation and grand success of green policy the organizations need to need to adopt new methods, technologies, and tools to create a positive impact towards the environment. Support from top management, mindset of working people, skilled people with green competencies, social awareness, a comprehensive reward system, continuous training and development programs would ensure that employee's wholehearted participation towards environmental sustainability across the organization.

\section{REFERENCES}

Alfred, A. M., \& Adam, R. F. 2009. Green management matters regardless. Academy of Management Perspectives, 23(3), 17-26.

Bansal, P., \& Roth, K. 2000. Why companies go green: A model of ecological responsiveness. Academy of Management Journal, 43(4), 717-736.

Barton, R. 2009. Is the grass any greener. The Independent on Sunday, 15(9), 8-13.

Bauer, T. N., Erdogan, B., \& Taylor, S. 2012. Creating and maintaining environmentally sustainable organizations: Recruitment and onboarding.

Beard, C., \& Rees, S. 2000. Green teams and the management of environmental change in a UK county council. Environmental Management and Health, 11(1), 27-38.

Bebbington, J. 2000. Sustainable development: a review of the international development, business and accounting literature.

Berns, M., Townend, A., Khayat, Z., Balagopal, B., Reeves, M., Hopkins, M., \& Kruschwitz, N. 2009. The business of sustainability: Imperatives, advantages, and actions. The Boston Consulting Group (BCG).

Berrone, P., \& Gomez-Mejia, L. R. 2009. Environmental performance and executive compensation: An integrated agency-institutional perspective. Academy of Management Journal, 52(1), 103-126.

Casler, A., Gundlach, M. J., Persons, B., \& Zivnuska, S. 2010. Sierra Nevada Brewing Company's thirtyyear journey toward sustainability. People and Strategy, 33(1), 44.

Chadwick, C. 2010. Theoretic insights on the nature of performance synergies in human resource systems: Toward greater precision. Human Resource Management Review, 20(2), 85-101.

Chen, C.-C., Lin, M.-M., \& Chen, C.-M. 2012. Exploring the mechanisms of the relationship between website characteristics and organizational attraction. The International Journal of Human Resource Management, 23(4), 867-885.

Chen, Z., Hossen, M. M., Muzafary, S. S., \& Begum, M. 2018. Green Banking for Environmental Sustainability-Present Status and Future Agenda: 
Experience from Bangladesh. Asian Economic and Financial Review, 8(5), 571-585.

Cherian, J., \& Jacob, J. 2012. Green marketing: A study of consumers' attitude towards environment friendly products. Asian Social Science, 8(12), 117.

Chun, R. 2009. Ethical values and environmentalism in China: Comparing employees from state-owned and private firms. Journal of Business Ethics, 84(3), 341-348.

Clair, J., \& Milliman, J. 2017. Best environmental HRM practices in the US Greening People (pp. 49-73): Routledge.

Collier, J., \& Esteban, R. 2007. Corporate social responsibility and employee commitment. Business Ethics: A European Review, 16(1), 19-33.

Davies, G., \& Smith, H. 2007. Natural resources. People Management(null), 26-31.

do Rosário Cabrita, M., Cruz-Machado, V., Matos, F., \& Safari, H. (2016). Green Knowledge: Developing a Framework That Integrates Knowledge Management and Eco-Innovation. Paper presented at the European Conference on Knowledge Management.

DuBois, C. L., \& Dubois, D. A. 2012. Strategic HRM as social design for environmental sustainability in organization. Human Resource Management, 51(6), 799-826.

Epstein, M. J., \& Roy, M. J. 1997. Using ISO 14000 for improved organizational learning and environmental management. Environmental Quality Management, 7(1), 21-30.

Flammer, C. 2013. Corporate social responsibility and shareholder reaction: The environmental awareness of investors. Academy of Management Journal, 56(3), 758-781.

Florida, R., \& Davison, D. 2001. Gaining from green management: environmental management systems inside and outside the factory. California Management Review, 43(3), 64-84.

Forman, M., \& Jorgensen, M. S. 2001. The social shaping of the participation of employees in environmental work within enterprises-experiences from a Danish context. Technology Analysis \& Strategic Management, 13(1), 71-90.

Glavas, A., Senge, P., \& Cooperrider, D. L. 2010. Building a Green City on a Blue Lake: a model for building a local sustainable economy. People and Strategy, 33(1), 26.

González-Benito, J., \& González-Benito, Ó. 2006. A review of determinant factors of environmental proactivity. Business Strategy and the environment, 15(2), 87-102.

Gregory, C. K., Meade, A. W., \& Thompson, L. F. 2013. Understanding internet recruitment via signaling theory and the elaboration likelihood model. Computers in Human Behavior, 29(5), 1949-1959.

Grolleau, G., Mzoughi, N., \& Pekovic, S. 2012. Green not (only) for profit: An empirical examination of the effect of environmental-related standards on employees' recruitment. Resource and Energy Economics, 34(1), 74-92.

Gully, S. M., Phillips, J. M., Castellano, W. G., Han, K., \& Kim, A. 2013. A mediated moderation model of recruiting socially and environmentally responsible job applicants. Personnel Psychology, 66(4), 935973.

Hanna, M. D., Rocky Newman, W., \& Johnson, P. 2000. Linking operational and environmental improvement through employee involvement. International Journal of Operations \& Production Management, 20(2), 148-165.

Harmon, J., Fairfield, K. D., \& Wirtenberg, J. 2010. Missing an opportunity: HR leadership and sustainability. People and Strategy, 33(1), 16.

Hossen, M. M., Begum, M., \& Zhixia, C. 2018. Present Status of Organizational Work-Life Balance Practices in Bangladesh: Employees Expectation and Organizational Arrangements. Journal of Eastern European and Central Asian Research, 5(1), 1-16.

Hossen, M. M., Uddin, M. N., \& Hossain, A. 2014. E-Commerce: A Scrutiny about Upgrading Environmental Commerce through Securing Environmental Sustainability. BUP JOURNAL, 1(2), 83-103.

IDRBT. 2013. Green Banking IIT, Hyderabad, Institute of Development And Research in Banking Technology.

Jabbour, C. J. C., de Sousa Jabbour, A. B. L., Govindan, K., Teixeira, A. A., \& de Souza Freitas, W. R. 2013. Environmental management and operational performance in automotive companies in Brazil: the role of human resource management and lean manufacturing. Journal of Cleaner Production, $47,129-140$.

Jabbour, C. J. C., Santos, F. C. A., \& Nagano, M. S. 2010. Contributions of HRM throughout the stages of environmental management: methodological triangulation applied to companies in Brazil. The International Journal of Human Resource Management, 21(7), 1049-1089.

Jackson, S. E., Renwick, D. W., Jabbour, C. J., \& Muller-Camen, M. 2011. State-of-the-art and future directions for green human resource management: Introduction to the special issue. German Journal of Human Resource Management, 25(2), 99-116.

Jones, D. A., \& Willness, C. R. 2013. Corporate Social Performance, Organizational Reputation, and. The Oxford handbook of recruitment, 298.

Jose Chiappetta Jabbour, C. 2011. How green are HRM practices, organizational culture, learning and teamwork? A Brazilian study. Industrial and Commercial Training, 43(2), 98-105.

Kitazawa, S., \& Sarkis, J. 2000. The relationship between ISO 14001 and continuous source reduction 
programs. International Journal of Operations \& Production Management, 20(2), 225-248.

Lai, K.-h., Cheng, T., \& Tang, A. K. 2010. Green retailing: factors for success. California Management Review, $52(2), 6-31$.

Liebowitz, J. 2010. The role of HR in achieving a sustainability culture. Journal of sustainable development, 3(4), 50.

Longoni, A., \& Cagliano, R. 2015. Environmental and social sustainability priorities: Their integration in operations strategies. International Journal of Operations \& Production Management, 35(2), 216-245.

Madsen, H., \& Ulhøi, J. P. 2001. Greening of human resources: environmental awareness and training interests within the workforce. Industrial Management \& Data Systems, 101(2), 57-65.

Malu, S., Agrawal, R., \& Jajoo, D. 2014. Gallery: TMU. Retrieved from TMU: http://tmu. ac. in/gallery/ viewpointsdcip2013/pdf/track3.

Mampra, M. 2013. Green HRM: Does it help to build a competitive service sector? A study. Paper presented at the Proceedings of tenth AIMS International Conference on Management.

Mandip, G. 2012. Green HRM: People management commitment to environmental sustainability. Research Journal of Recent Sciences, ISSN, 2277, 2502.

Marcus, B. H., Lewis, B. A., Williams, D. M., Dunsiger, S., Jakicic, J. M., Whiteley, J. A., . . Tate, D. F. 2007. A comparison of Internet and print-based physical activity interventions. Arch Intern Med, 167(9), 944-949.

Marhatta, S., \& Adhikari, S. 2013. Green HRM and sustainability. International eJournal Of Ongoing Research in Management \& IT.

Mathapati, C. 2013. Green HRM: A strategic facet. Tactful Management Research Journal, 2(2), 1-6.

McDonagh, P., \& Prothero, A. 1997. Green management: A reader: International Thomson Business Press.

MOHD-YUSOFF, Y., \& MOHD-YUSOFF, Y. 2015. Strategic green human resource management as a critical success factors for environmental performance in Malaysia. CGHRM, 163.

Mugenda, A. 2003. Research methods Quantitative and qualitative approaches by Mugenda. Nairobi, Kenya.

Murari, K., \& Bhandari, M. 2011. Green HR: Going green with pride.

Muster, V., \& Schrader, U. 2011. Green work-life balance: A new perspective for green HRM. German Journal of Human Resource Management, 25(2), 140-156.

Opatha, H., \& Arulrajah, A. A. 2014. Green human resource management: Simplified general reflections. International Business Research, 7(8), 101.
Phillips, L. 2007. Go green to gain the edge over rivals. People Management, 23(9).

Philpott, J., \& Davies, G. 2007. Labour Market Outlook. (Quarterly Survey Report, Summer). London: CIPD/KPMG, 1-22.

Pillai, R., \& Sivathanu, B. 2014. Green Human Resource Management. Zenith International Journal of Multidisciplinary Research, 4(1), 72-82.

Ramus, C.A. 2002. Encouraging innovative environmental actions: what companies and managers must do. Journal of World Business, 37(2), 151-164.

Remmen, A., \& Lorentzen, B. 2000. Employee participation and cleaner technology: learning processes in environmental teams. Journal of Cleaner Production, 8(5), 365-373.

Renwick, D., Redman, T., \& Maguire, S. 2008. Green HRM: A review, process model, and research agenda. University of Sheffield Management School Discussion Paper, 1, 1-46.

Renwick, D., Redman, T., \& Maguire, S. 2013. Green HRM: teaching and learning guide. International Journal of Management Reviews.

Renwick, D. W., Redman, T., \& Maguire, S. 2013. Green human resource management: A review and research agenda. International Journal of Management Reviews, 15(1), 1-14.

Simms, J. 2007. Direct action. People Management, $19,36-39$. .

Simpson, D., \& Samson, D. 2010. Environmental strategy and low waste operations: exploring complementarities. Business Strategy and the environment, 19(2), 104-118.

Stone, L. 2000. When case studies are not enough: the influence of corporate culture and employee attitudes on the success of cleaner production initiatives. Journal of Cleaner Production, 8(5), 353-359.

Stringer, L. 2010. The green workplace: Sustainable strategies that benefit employees, the environment, and the bottom line: St. Martin's Press.

Surroca, J., Tribó, J. A., \& Waddock, S. 2010. Corporate responsibility and financial performance: The role of intangible resources. Strategic management journal, 31(5), 463-490.

Svensson, G., Høgevold, N. M., Petzer, D., Padin, C., Ferro, C., Klopper, H., . . . Wagner, B. 2016. Framing stakeholder considerations and business sustainability efforts: a construct, its dimensions and items. Journal of Business \& Industrial Marketing, 31(2), 287-300.

Trust, C. 2006. Office Based Companies: Maximising Energy Savings in an Office Environment. Report No. CT007, London: Carbon Trust, 1-19.

Unnikrishnan, S., \& Hegde, D. 2007. Environmental training and cleaner production in Indian industry-A micro-level study. Resources, Conservation and Recycling, 50(4), 427-441. 
Victor, D. G. 2011. The collapse of the Kyoto Protocol and the struggle to slow global warming: Princeton University Press.

Wehrmeyer, W. 2017. Greening people: Human resources and environmental management: Routledge.

Yusoff, Y. M., Ramayah, T., \& Othman, N.-Z. 2015. Why examining adoption factors, HR role and attitude towards using E-HRM is the start-off in determining the successfulness of green HRM. J.
Adv. Manag. Sci, 3.

Zamil, F., \& Hossen, M. M. 2012. Problems and prospects of telecommunication sector of Bangladesh: A critical review (Vol. 4, pp. 16-25): New Media and Mass Communication.

Zoogah, D. B. 2011. The dynamics of Green HRM behaviors: A cognitive social information processing approach. German Journal of Human Resource Management, 25(2), 117-139.

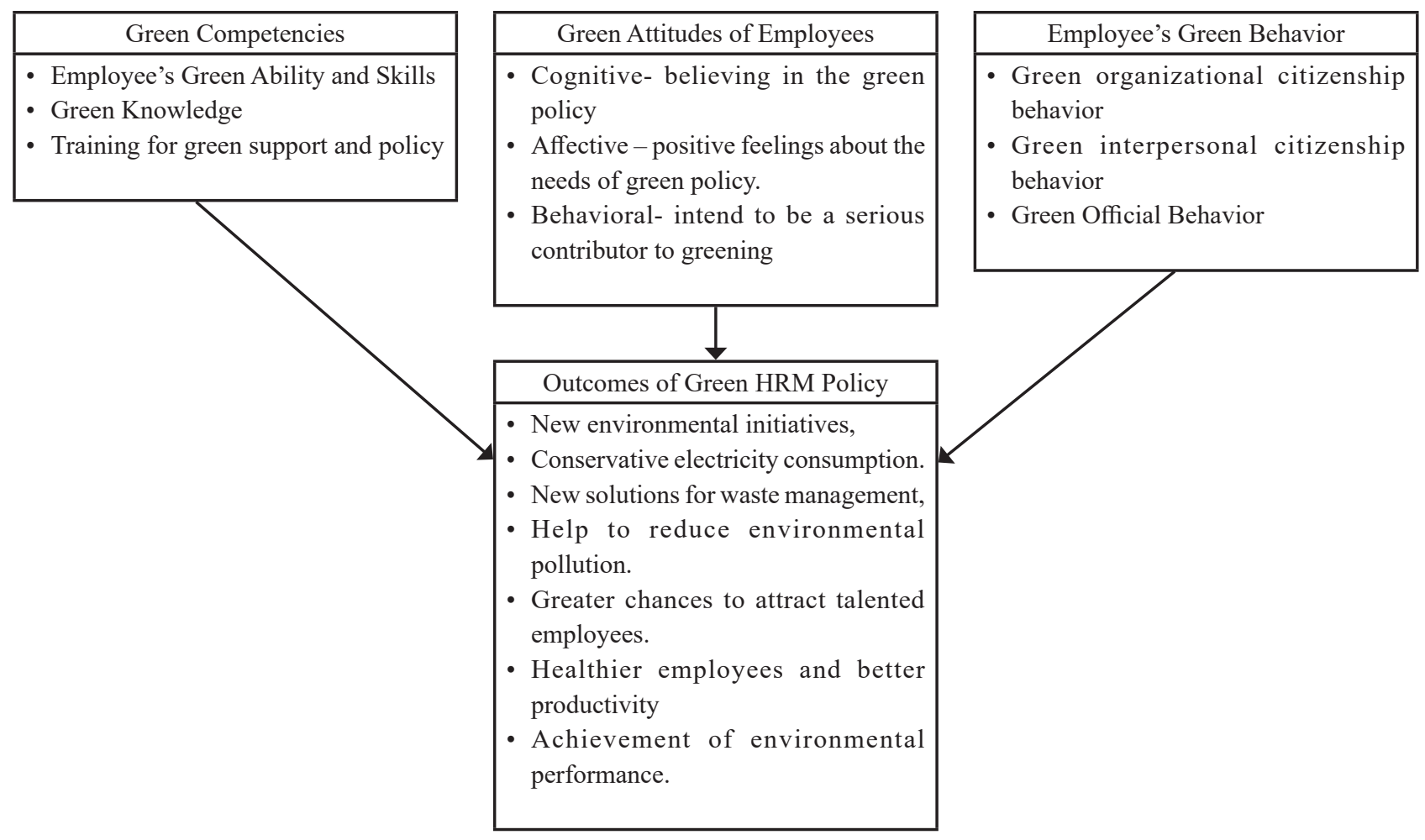

(Source: Compiled by authors)

Figure 1. Requirements of Green HRM Policy 
Table 1. HR Function and Strategies/Suggestions to make the HR Function Greener

\begin{tabular}{|c|c|}
\hline HR Functions & es/ suggestions to make the HR function greener \\
\hline $\begin{array}{c}\text { Acquisition functions: } \\
\text { (HRP, Recruitment, } \\
\text { Selection, } \\
\text { Socialization) }\end{array}$ & $\begin{array}{l}\text { - Developing green employer image and mention the greening endeavors in organization's websites. } \\
\text { - Considering green competencies and environmental dimension in job specification and job descriptions. } \\
\text { - Providing green issues in the job advertisements and communication it all through the recruitment process. } \\
\text { - Listing green standards for screening the candidate and also consider the resumes of 'Green-aware' } \\
\text { candidates for the first list. } \\
\text { - Selecting those candidates who are adequately aware of greening and practicing greening as consumers } \\
\text { under their private life domain. } \\
\text { - Introducing green efforts of the organization in the induction process and showing Green citizenship } \\
\text { behavior of current employees. }\end{array}$ \\
\hline $\begin{array}{l}\text { Training and } \\
\text { Development }\end{array}$ & $\begin{array}{l}\text { - Considering the green training needs when analyses the training needs. } \\
\text { - Provide the right knowledge about greening through an exclusive training program about green roles and } \\
\text { green HR functions. } \\
\text { - Forming a 'green teams' to produce general awareness and specific training in Environmental Management } \\
\text { (EM). } \\
\text { - Providing chances to improve green personal skills through job rotation, job sharing, and other techniques. } \\
\text { - Training future green managers on aspects of safety, energy efficiency, waste management and recycling. } \\
\text { - All the training programs will be paperless and technology concern. }\end{array}$ \\
\hline $\begin{array}{l}\text { Motivation } \\
\text { Functions: (Compen- } \\
\text { sations, Employee } \\
\text { involvement, and } \\
\text { empower-ment) }\end{array}$ & $\begin{array}{l}\text { - Rewarding the eco-performers financially or non-financially (awards, praises and recognition). } \\
\text { - Offering benefit package for acquiring skills of green leadership, green initiatives, waste-reduction, } \\
\text { recycling practices of employees. } \\
\text { - Promoting suggestion schemes for innovative ideas, encouraging leadership to motivate others to green } \\
\text { activities and rewarding these. } \\
\text { - Ensuring the employee involvement and empowerment to make them happy and feeling psychologically } \\
\text { empowered. } \\
\text { - Assisting management and employees to remove their own carbon emissions through e-HR. } \\
\text { - Ensuring a green office (with enough light and air) which is environmentally sensitive, resource efficient } \\
\text { and socially responsible. } \\
\text { - Introducing an employee help-line and wellness program for guidance in green matters. }\end{array}$ \\
\hline $\begin{array}{l}\text { Maintenance } \\
\text { Functions: } \\
\text { (Performance } \\
\text { management, } \\
\text { Discipline } \\
\text { management, and } \\
\text { Employee relations) }\end{array}$ & $\begin{array}{l}\text { - Integrating green standards in the performance appraisal system and judge employee's according to the } \\
\text { mentioned green criteria. } \\
\text { - Communicating an individual's roles, responsibilities and targets in achieving green-targets. } \\
\text { - Developing green information system and audits and also Penalizes for non-compliance of standards and } \\
\text { targets. } \\
\text { - Employing ecologist or experts to formulate and implement environment management systems and } \\
\text { policies. } \\
\text { - Developing green commuting habits like e-work, video conferencing, flexi-hours, car-pooling, free or } \\
\text { discounted transportation passes, etc. to reduce travel and emission. } \\
\text { - Promoting green printing through adopting '3R' approach to 'Reduce-Recycle-Reuse' resources. } \\
\text { - Developing a code of conduct of green issues with mentioning disciplinary system to punish employees } \\
\text { who violate the rules. } \\
\text { - Conducting an exit interview to measure employee's perceptions on organizations green practices when } \\
\text { any dismissal or breach of tenures. } \\
\text { - Acting within local government expectations and environmental laws to align strategies with those of } \\
\text { suppliers to avoid fines. }\end{array}$ \\
\hline
\end{tabular}

